\title{
Serum lactoferrin in lepromatous leprosy patients
}

\author{
OM PARKASH, B. K. GIRDHAR \& U. SENGUPTA \\ Central JALM A Institute for Leprosy, Tajganj, Agra-282 001, India
}

\author{
Accepted for publication 5 July 1993
}

\begin{abstract}
Summary The serum concentrations of lact oferrin were determined by competitive enzyme immunoassay in the sera of 38 lepromatous leprosy patients and 16 healthy volunteers. Of the 38 lepromatous patients, 25 were without any sign of reactions while 13 were suffering from ENL type of reactions. The lactoferrin levels, in both types of patients, were observed to be significantly higher $(P<0 \cdot 01$ and $<0.001$, respectively) than in that of healthy volunteers. The rise in lact oferrin level in reactive patients was also higher $(P<0 \cdot 05)$ when compared to those without reactions. The serum lactoferrin levels were also found to be associated with bacterial load $(r=0.414 ; P<0.01)$ indicating that in lepromatous leprosy patients, lact oferrin may not be very effective in preventing the growth of Mycobacterium leprae. Further studies to improve the understanding of the role of elevated levels of lactoferrin in pathogenesis of lepromatous leprosy patients and in establishing its possible use in predicting the occurrence of ENL type of reactions would be worthwhile pursuing.
\end{abstract}

\section{Introduction}

Leprosy, a chronic disease caused by $M$. leprae, is a spectral disease that ranges from tuberculoid leprosy on one hand to lepromatous leprosy on the other. Patients suffering from the lepromatous type of leprosy lack any immunity against $M$. leprae which, therefore, can unrestrictedly multiply inside the body. Due to the dissemination of $M$. leprae into various parts of the body, a host of components of the immune system are influenced, giving rise to a variety of immuno-biochemical changes, including a rise in the immune complex level. ${ }^{1-6}$ However, there has never been a report on the status of lactoferrin, an iron binding protein, ${ }^{7.8}$ in leprosy patients. Since $M$. leprae and immune complexes are known to interact with polymorphonuclear leucocytes ${ }^{9-11}$ (the main lactoferrin producing cells), ${ }^{12,13}$ and accumulation of polymorphonuclear leucocytes is a salient feature of erythema nodosum leprosum (ENL) lesions, ${ }^{14}$ we felt it important to determine the levels of lactoferrin in sera from lepromatous leprosy patients with and without ENL. As far as we know, this is the first study on this subject. 


\section{Materials and methods}

SERA SAMPLES

Sera samples were collected from lepromatous leprosy (LL) patients who attended the out-patient department of the Central JALMA Institute for Leprosy, Agra, India. Although most of the patients were under treatment they all showed an active form of the disease; 25 patients were without any sign of lepra reaction while 13 patients were having ENL type of reactions. The sera collected from 16 normal healthy individuals formed controls for the study. The 3 groups were matched for age and sex. All the sera collected was stored at $-70^{\circ} \mathrm{C}$ until used.

\section{REAGENTS}

Bovine-serum albumin, lactoferrin and tween-20 were purchased from the Sigma Chemical Company, St. Louis, U.S.A. Sheep anti-human lactoferrin antibody (Ig fraction) was purchased from Serotec, Oxford, U.K. and peroxidase conjugated rabbit anti-sheep antibody (affinity pure IgG) was collected from Jackson Immuno-research Lab, Inc., Baltimore Pike, West Grove, PA19390, U.S.A. All the other chemicals used for making the buffers were of reagent grade.

\section{BACTERIOLOGICAL INDEX}

The bacteriological status of leprosy patients was studied by determining the bacterial index (BI). Slit-skin smears were taken from 4 sites, the left and right lobes of both the ears, and 2 representative skin lesions. The smears were stained according to ZiehlNeilson's method. The average bacterial density was calculated following the Ridley's logarithmic scale. ${ }^{15}$

\section{MEASUREMENT OF SERUM LACTOFERRIN}

The lactoferrin levels in the sera samples were measured by competitive enzyme linked immunosorbent assay (ELISA). For this assay lactoferrin was diluted to $2.0 \mu \mathrm{g} / \mathrm{ml}$ in carbonate buffer ( $\mathrm{pH} 9 \cdot 6$ ) and $100 \mu \mathrm{l}$ of this suspension was added to each well. The plates (Nunc, Denmark) were kept at $4{ }^{\circ} \mathrm{C}$ overnight for coating. After this, the wells were washed 3 times with phosphate-buffered saline supplemented with $0 \cdot 1 \%$ tween-20 (PBST). Excess binding sites, for non-specific binding of proteins, were blocked at $37^{\circ} \mathrm{C}$ for $2 \mathrm{hr}$, with $1 \% \mathrm{BSA}(200 \mu \mathrm{l} /$ well) prepared in PBST. Next, $50 \mu \mathrm{l}$ of the undiluted serum sample was added to each well and a

lactoferrin antibodies, diluted $(1: 5000)$ in PBST. For each test at least 3 wells were used. The plates were then kept at $37^{\circ} \mathrm{C}$ for $2 \mathrm{hr}$, washed, dried and further incubated for 45 minutes with peroxidase labelled anti-sheep antibodies diluted $(1: 5000)$ in PBST. After washing the plates, the colour in the wells was developed by adding $100 \mu \mathrm{l} /$ well of the substrate (1,2-orthophenylenediamine dihydrochloride) for 20 minutes. Finally, the enzymatic reaction was stopped by $50 \mu \mathrm{l} /$ well of $7 \% \mathrm{H}_{2} \mathrm{SO}_{4}$. The optical density values were read by using an ELISA reader (Titertek, Multiscan, Flow Laboratories, U.K.). The values of serum lactoferrin were calculated using a standard curve obtained with purified lactoferrin. 


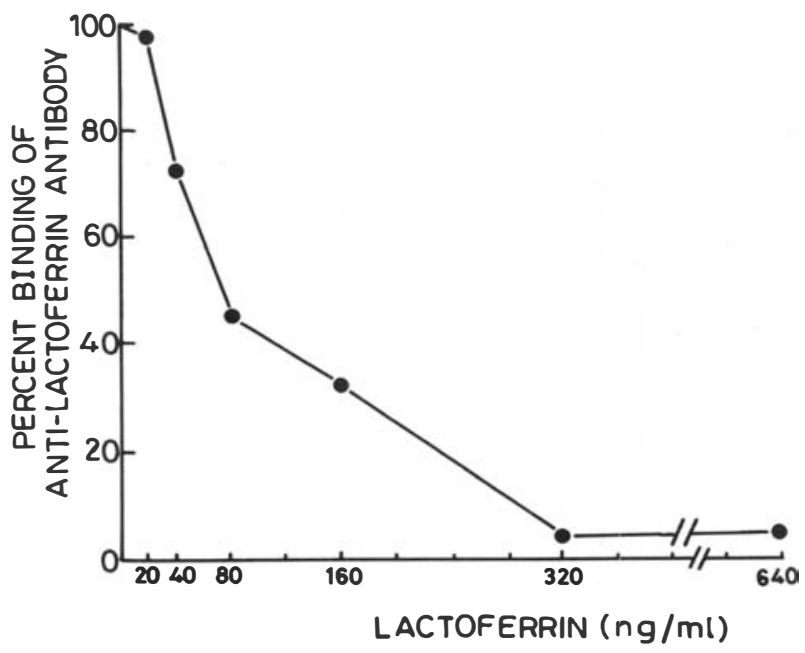

Figure 1. Standard curve for lactoferrin.

\section{Results}

A standard curve was obtained on graph paper by measuring the percent binding (in the presence of several concentrations of the purified lactoferrin) of anti-lactoferrin antibodies to the lactoferrin coated wells. The binding of anti-lactoferrin antibody, in the absence of purified lactoferrin, was considered as 100\%. A dose-dependent, inverse relationship between the lactoferrin level (up to $320 \mathrm{ng} / \mathrm{ml}$ ) and the binding of antilactoferrin antibody was obtained (Figure 1). Thus less binding of anti-lactoferrin antibody indicated higher concentration of lactoferrin, and vice versa.

Lactoferrin levels in the sera of the controls and the lepromatous leprosy patients were measured using competitive ELISA. Figure 2 depicts the lactoferrin levels in sera from each subject. The range of lactoferrin levels in the sera from the controls was $0 \cdot 32-1 \cdot 58 \mu \mathrm{g} /$ $\mathrm{ml}$, in lepromatous leprosy patients without reactions it was $0.44-5.58 \mu \mathrm{g} / \mathrm{ml}$, while in those having ENL type of reactions it varied from 1.08 to $6 \cdot 24 \mu \mathrm{g} / \mathrm{ml}$. The mean ( \pm S.D.) lactoferrin level $(3.25 \pm 2.01 \mu \mathrm{g} / \mathrm{ml}$ and $1.95 \pm 1.47 \mu \mathrm{g} / \mathrm{ml})$ in the sera of both types (reactive and non-reactive, respectively) of lepromatous leprosy patients were significantly higher $(P<0.001$ and $P<0.01)$ than that $(0.99 \pm 0.46 \mu \mathrm{g} / \mathrm{ml})$ of the controls. We also found that lactoferrin in reactive lepromatous patients was higher $(P<0.05)$ compared to non-reactive leprosy patients. Further analysis showed that lactoferrin concentration in $28 \%$ ( 7 out of 25 ) LL patients were below the mean level of the controls, whereas all ENL patients showed above the controls' mean value.

In order to better understand the anti- $M$. leprae activity of lactoferrin in lepromatous leprosy patients, the correlation between the lactoferrin level and the bacterial index was also investigated. A positive correlation $(r=0.414 ; P<0 \cdot 01)$, though weak, was noted between the lactoferrin level and bacterial load (Figure 3 ).

\section{Discussion}

The present study demonstrates, for the first time, elevated concentrations of lactoferrin 


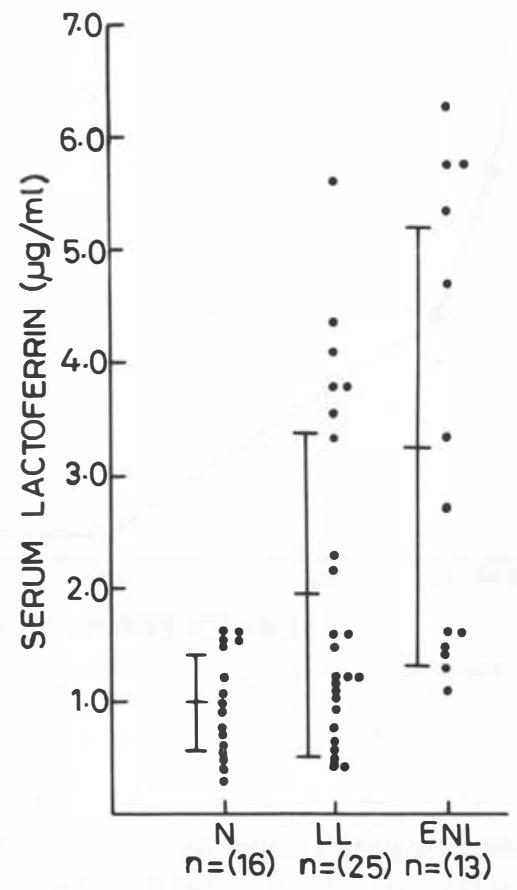

Figure 2. Lactoferrin levels in sera from lepromatous leprosy patients without reactions (LL), from LL patients suffering from erythema nodosum leprosum (ENL) type of reaction and from healthy controls (N). Vertical bar indicates mean \pm S.D. for each group.

in lepromatous leprosy patients as a group. However, there were patients whose lactoferrin was below the mean value of the controls. The individual response to chemotherapy and the genetic make up of these patients might cause this. It is noteworthy that the lactoferrin level was found to be still higher in ENL cases than those without ENL. From these findings it appears that a continuous rise of lactoferrin level in lepromatous patients might prove to be helpful in predicting the occurrence of ENL type of reactions. To confirm this theory, a follow-up study of lepromatous patients is required. It would also be interesting to know whether lactoferrin has any role in the pathogenesis of lepromatous leprosy, and even more interesting if it affected ENL patients.

There are some possible mechanisms to explain the increased lactoferrin production in lepromatous leprosy patients. Polymorphonuclear leucocytes (PMNs) are an important component of the immune system and contain lactoferrin in their specific storage granules. ${ }^{12,13}$ On their activation by a variety of stimuli, for instance the phagocytosis of microbes $^{16-18}$ or interaction with immune complexes, ${ }^{10,11}$ the lactoferrin from these granules is discharged both in phagosomes and to the external environment. Phagocytosis of $M$. leprae by PMNs has been described in lepromatous leprosy patients ${ }^{9}$ and it has also been demonstrated that the immune complex level is elevated. ${ }^{1,4}$ It is possible that elevation in the levels of serum lactoferrin in lepromatous leprosy patients may be caused by the stimulation of PMNs by phagocytosed $M$. leprae and immune complexes. The higher level of lactoferrin in reactional patients could be attributed to their higher load of 


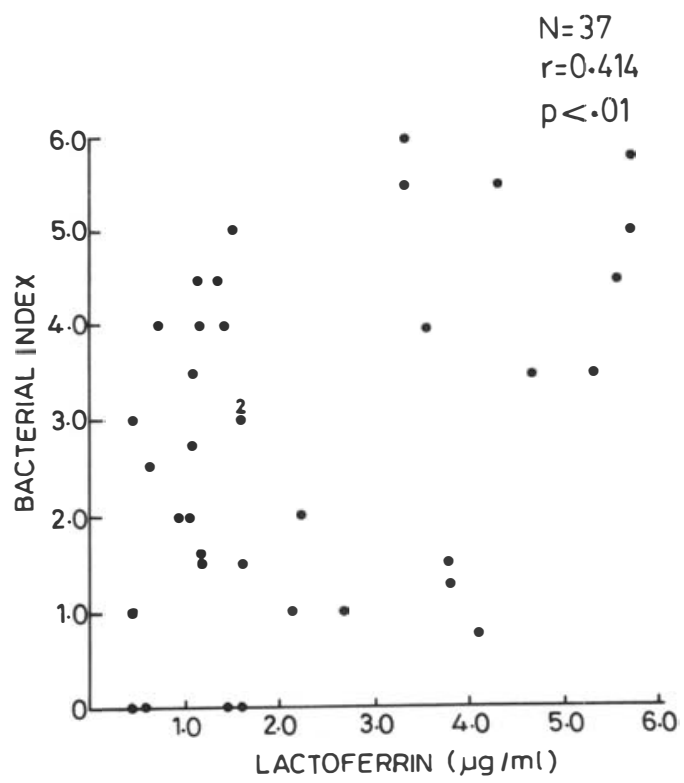

Figure 3. Correlation of lactoferrin levels with bacterial index in lepromatous leprosy patients.

immune complexes present, compared to patients not suffering from reactions. ${ }^{4}$ Further, the spillover during tissue necrosis due to lysis of PMNs accumulated at the site of the reactive lesions ${ }^{14}$ might also add to the lactoferrin level in ENL patients.

Evidence shows that lactoferrin mediates the antibacterial activity against a wide range of micro-organisms, including Gram negative and Gram positive bacteria. ${ }^{78,19,20}$ Some of the mechanisms involved in antibacterial action of lactoferrin include the impedency of iron utilization by bacteria, interfering with the metabolism of microbial cells, destabilization of the microbial cell wall, and stimulation of intracellular killing of micro-organisms by phagocytes, etc. ${ }^{7.8}$ In the present study a positive correlation was observed between $M$. leprae load and lactoferrin levels which appears to suggest that lactoferrin is unable to prevent bacterial multiplication inside the host.

\section{Acknowledgments}

We thank Lepra, U.K., for supplying some of the reagents used in this study. We thank P. N. Sharma, M. Singh, M. Alam, K. Kulshreshta, K. L. Verma and D. Bahadur for their assistance and Hari Om and Neeraj for photographic help.

\section{References}

1 Bjorvatn B, Barnetson R St C, Kronvall GK, Zubler RH, Lambert PH. Immune complexes and complement hypercatabolism in patients with leprosy. Clin exp Imm, 1976; 26: 388-96.

2 Kelkar SS, Mondkar AD, Warawdekar W. Serum immunoglobulins in leprosy. Lepr India, 1979; 51: 189-93. 
${ }^{3}$ Chawahan, RN, Sirdeshpande SH, Zawar PB, Sengupta SR, Yemul VL. Alpha-1-antitrypsin in lepra reaction. $J$ Assoc Phys India, 1982; 30: 75-7.

${ }^{4}$ Ramanathan VD, Parkash O, Ramu G, Parker D, Curtis J, Sengupta U, Turk JL. Isolation and analysis of circulating immune complexes in leprosy. Clin Immunol Immunopath, 1984; 32: 261-8.

5 Thompson RA, Sukumaran KD, Rajgopalan K. Inappropriate response to Mycobacterium leprae infection. C-reactive protein in man and serum amyloid $\mathrm{P}$ in mice. Clin exp Imm, 1985; 61: 329-35.

${ }^{6}$ Silva CL, Foss NT. Tumor necrosis factor in leprosy patients. J Infect Dis, 1989; 159: 787-90.

7 Weinberg ED. Iron withholding: a defence against infection and neoplasia. Physiol Rev, 1984; 64: 65-102.

8 Sanchez L, Calvo M, Brock JH. Biological role of lactoferrin. Arch Dis Child, 1992; 67: 657-61.

9 Drutz DJ, O’Neill SM, Levy L. Viability of blood borne Mycobacterium leprae. J Infect Dis, 1974; 130: 288 92.

10 Henson PM. Interaction of cells with immune complexes: adherence, release of constituents and tissue injury. $J$ exp Med, 1971; 134 (suppl): 114.

11 Leffel MS, Spitznagel JK. Intracellular and extracellular degranulation of human polymorphonuclear azurophil and specific granules induced by immune complexes. Infect Immun, 1974; 10: 124-9.

12 Masson PL, Heremans JF, Schonne E. Lactoferrin, an iron binding protein in neutrophilic leucocytes. $J$ Exp Med, 1969; 130: 643-58.

13 Spitznagel JK, Dalldorf FG, Leffel MS, Folds JD, Welsh IRH, Cooney MH, Martin LE. Character of azurophil and specific granules purified from human polymorphonuclear leucocytes. Lab Invest, 1974; 30: 774-85.

14 Ridley MJ, Ridley DS. The immunopathology of erythema nodosum leprosum: The role of extravascular complexes. Lepr Rev, 1983; 54: 95-107.

15 Ridley DS, Jopling WH. Classification of leprosy according to immunity: A five group system. Int J Lepr, 1966; 34: 255-73.

16 Bainton DF. Sequential degranulation of polymorphonuclear leucocytes granules during phagocytosis of micro-organisms. J Cell Biol, 1970; 47: 11 a.

17 Hurlen B, Olsen I, Lingaas E, Midtvedt T. Neutrophil phagocytosis of Treponema denticola as indicated by extracellular release of lactoferrin. Acta Pathol Microbiol Immunol Scand Sect, 1984; B92: 171-3.

18 Laforce FM, Boose DS. Release of lactoferrin by polymorphonuclear leucocytes after aerosol challenge with Escherichia coli. Infect Immun, 1987; 55: 2293-5.

19 Oram JD, Reiter B. Inhibition of bacteria by lactoferrin and other iron-chelating agents. Biochim Biophys Acta, 1968; 170: 351-65.

20 Arnold RR, Brewer M, Gauthier JJ. Bactericidal activity of human lactoferrin: sensitivity of a variety of micro-organisms. Infect Immun, 1980; 28: 893-8. 


\title{
Lactoferrine sérique chez les sujets lépreux lépromateux
}

\author{
O. Parkash, B. K. Girdhar et U. Sengupta
}

Résumé Nous avons déterminé les concentrations sériques de lactoferrine par test immunoenzymatique par compétition, dans le sérum de 38 sujets lépreux lépromateux et de 16 volontaires en bonne santé. 25 des 38 sujets lépromateux n'ont présentés aucun signe de réaction tandis que 13 ont souffert de réactions du type ENL. Chez ces deux types de sujets nous avons observé que les concentrations de lactoferrine étaients significativement plus élevées $(P<0,01$ et $<0,01$ respectivement) que chez les volontaires en bonne santé. La hausse du taux de lactoferrine était également plus élevée $(P<0,05)$ chez les sujets qui ont présenté des réactions que chez ceux qui sont restés sans réaction. Nous avons également observé que les concentrations sériques de lactoferrine étaient associées à la charge bactérienne $(\mathrm{R}=0,414 ; P<0,01)$ ce qui indique que chez les sujets atteints de lèpre lépromateuse, la lactoferrine n'est peut-être pas très efficace pour empêcher la croissance du $M$ ycobacterium leprae. Il y aurait lieu de faire d'autres études pour comprendre le rôle des concentrations élevées de lactoferrine dans la pathogénie de la lèpre lépromateuse et pour déterminer son utilisation possible dans la prévision de l'occurence des réactions de type ENL.

\section{Lactoferrina del suero en pacientes de lepra lepromatosa}

\author{
O. Parkash, B. K. Girdhar y U. Sengupta
}

Resumen Mediante el inmunoensayo de enzimas competitivas se determinaron las concentraciones de lactoferrina en el suero de 38 pacientes de lepra lepromatosa y 16 voluntarios sanos. De los 38 pacientes lepromatosos, 25 no presentaron signos de reacciones, mientras que 13 pacientes sufrieron reacciones de tipo ENL. Los niveles de lactoferrina observados en ambos tipos de pacientes fue significativamente superior $(P<0,01$ y $<0,01$, respectivamente) que el de los voluntarios sa nos. El aumento del nivel de lactoferrina también fue superior en los pacientes reactivos $(P<0,05)$ comparado con el de los pacientes no reactivos. También se observó que los niveles de lactoferrina en el suero están relacionados con la carga bacteriana $(r=0,414$; $P<0,06)$, lo cual señala que en los pacientes de lepra lepromatosa la lactoferrina tal vez no sea un medio muy eficaz para prevenir el aumento de Mycobacterium leprae. Bien valdría la pena ef ectuar mayores estudios para comprender el papel que desempeñan los niveles elevados de lactoferrina en la patogénesis de los pacientes de lepra lepromatosa, y para establecer su posible uso en el pronóstico de la incidencia de reacciones de tipo ENL. 